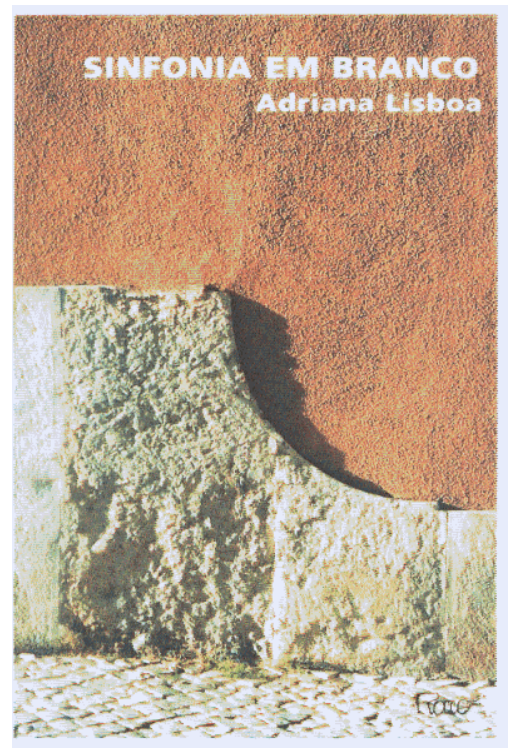

\title{
Uma narrativa doce e precisa
}

Quando se fala da atual produção romanesca brasileira, geralmente vem logo à baila a consagrada obra de Rubem Fonseca ou de seus clones. Por questões que vão desde o coleguismo empurrista até o marketing vaidoso de alguns autores (quem produz literatura precisa mesmo de assessoria de imprensa?), está se moldando lentamente uma pequena esfera diante da qual giram os satélites formadores das práticas leitoras. E assim o já minguado público consumidor de livros tende a restringir suas preferências a um mínimo conjunto de títulos pré-estabelecidos como um novo cânone, em detrimento da variedade de boas opções que têm saído das editoras.

E é desse grupo, livre de maneirismos e out-doors, que desponta uma pérola intitulada "Sinfonia em branco" (Rio de Janeiro: Rocco, 2001. 224 págs.), segundo romance da carioca Adriana Lisboa. Apesar de ter apenas 31 anos, a autora conta com uma bagagem de vida bem profícua para a atividade de compor narrativas: foi cantora, flautista e professora. As reminiscências da infância na fazenda, o Mestrado em literatura brasileira e o trabalho de tradutora também contribuíram para o resultado do novo livro.

Ao longo da leitura é possível retirar sentido da capa escolhida, que transmite a idéia de uma porosidade quase indelével, sugerindo ainda a imagem de um abismo feito de pedra que, de fato, percorrerá toda a obra. A foto do português Henrique Dinis da 
Gama, na verdade, é um detalhe de uma rua, assim como todo o romance se constrói pela observação minuciosa de pequenas coisas e dos significados que elas ofertam. $\mathrm{O}$ título faz referência a um quadro do

pintor inglês Whistler contendo uma mulher vestida de branco, mesclando som, imagem e palavra numa mesma metáfora.

A trama tem como centro as duas irmãs Clarice e Maria Inês. Em torno de ambas giram segredos, confissões, arrependimentos, e sobretudo uma cumplicidade muda. E também paixões e ódios que, de tão bem descritos nos seus efeitos sofridos pelo tempo, em alguns momentos fazem lembrar a força de "O morro dos ventos uivantes", de Emily Brontë, romance que, segundo Raquel de Queiroz, é "talvez o maior livro de ficção escrito por mulher desde que no mundo se conhece a arte de escrever”. A comparação é justa.

Mas o que faz de "Sinfonia em branco" um grande romance não é a história que ele conta, e sim o modo como as personagens atuam. Com extrema delicadeza e até uma certa ternura, nota-se sempre uma evasão para um micromundo contido num detalhe do ambiente, num som distante ou mesmo na suprema grandeza de um silêncio. Desse modo, a prosa vai oscilando entre os fatos ocorridos e as pulsões interiores provocadas por eles, revelando a densidade psicológica que existe por trás de situações aparentemente simples.

O livro chama a atenção pela boa capacidade de conduzir o leitor. A todo momento são fornecidas informações que vão seduzindo e criando expectativas, reveladas total ou parcialmente de acordo com o ritmo que a narradora-regente impõe, inclusive pela contenção presente em praticamente todas as personagens: "Maria Inês fez uma pausa, avaliou o silêncio na ponta da língua e sentiu seu gosto doce-azedo, como o das balas de tamarindo." O que não se diz passa a ter uma crescente relevância.

"Sinfonia em branco" deve ser lido devagar. Saboreado e apreciado como se fosse uma bebida rara. Adriana Lisboa conseguiu eficazmente captar o poético que reside nos detalhes cotidianos, costurando com palavras uma sinfonia de silêncios. 